\title{
FOLIAR RESPONSES OF TREE SEEDLINGS TO DIFFERING LIGHT AND TOPOGRAPHIC POSITIONS IN A SINHARAJA FOREST
}

\author{
M.H.D Saumyamali and B.M.P. Singhakumara \\ Department of Forestry and Environmental Science, University of Sri Jayewardenepura
}

\begin{abstract}
Light is one of the most demanding and limiting factor in the lowland rain forests. Here we studied seedling foliar responses (anatomy and morphology) of nine tree species in genera Shorea, Dipterocarpus, Mesua and Syzygium to different light environments (gap and understory) across three topographies (valley, midslope and ridge). There were significant differences in anatomical and morphological trails among species due to differing light and topographic positions. All species had higher anatomical (thickness of leaf blade, upper and lower epidermis cell years, palisade mesophyll cell layers, cuticle layer thickness and stomatal density) and leaf morphological tails ( single leaf area, length, width, drip-tip length and petiole length) in canopy gaps than in the understory. Among the species Syzygium makul had the thickest leaf blade in all gaps of each topography. Shorea megistophylla had thickest upper epidermal in two lights and across topographies. Shorea disticha and Shorea megistophylla showed thickest palisade layer. S. makul was greater in stomatal density (number of stomata per unit area). Shorea megistophylla and D.s zeylanicus showed higher leaf area than other species. When compared the measured foliar responses $S$. megistophylla is most suitable for valley, while D. zeylanicus, M. ferrea, S. makul and S. rubicundum for mid-slope sites. Mesua nagassarium, $S$. worthingtonii for ridge tops in both gap and the understory light environments. Finding indicate that the foliar traits are partially important in determination of species adaptation to particular light environment within the rain forest.
\end{abstract}

Key words: Topography, Canopy gap, Understory, Light, Leaf anatomy, Leaf morphology, Shorea, Syzygium, Mesua, Dipterocarpus.

\section{INTRODUCTION}

Tropical rain forests are one of the most dense ecosystems in the world. In Sri Lanka, agricultural activities, developments, residents, timber and monoculture plantations have fragmented and degraded these natural forests (Gunatilleke \& Gunatilleke 1985, 1991). Sinharaja is the largest virgin tropical rainforest remaining in Sri lanka. There is various micro sites in tropical rain forests and canopy disturbances are the reason for processing these micro sites and competition. It is discrete event that disrupt the structure and change in light environment, soil moisture, and soil nutrients. A single-tree disturbance may be relevant at the stand scale but not at the landscape scale. The small and medium size gaps had limited impacts on the species composition. Such gaps are crucial for regeneration of top canopy and pioneer species that are important in maintaining species diversity. Because natural gap phase processes plays an important role in biomass dynamics of tropical forests (Feeley 2007). A gap size varies within a particular part of forest topography; the largest in valley and smallest on ridge top (Ashton, 1992 cited in Ediriweera 2008). Most tropical rain forest tree species appear to dependent on these gaps for their successful regeneration (Whitmore, 1978). Light is a key resource controlling the development of tree seedlings in the tropical rain forests. The size of a gap has to be identified as the main determinant of both the amount and radiation of light that penetrates the forest floor (Brown, 1995). Patterns of light availability are important to ecology of plants in gap and understory (Brokaw, 1985). Availability of light in the understory causes the forest dynamics. PAR (Photo synthetically Active Radiation) is a limiting resource to the forest understory and according to that varies types of micro sites can be formed (Youny \& Giese 1990). Species can be identified with particular adaptations with best survival of its forest sites. Understory light environments are affected by many factors,

Proceedings of the $15^{\text {th }}$ International Forestry and Environment Symposium, 26-27 November 2010.

Published by Department of Forestry and Environmental Science, University of Sri Jayewardenepura, Sri Lanka. 
including over story species composition, successional stage, local path history and the slope, aspect, latitude and climate of the site (Canham, et al 1990).

The leaf is the morphologically and anatomically important plant organ (Fahn, 1990), and it is the specialized organ which the function of photosynthesis is centered. Seedling grown in different light environments and topographic positions has different morphological and anatomical adaptations. Here we studied the leaf anatomical and morphological differences of nine dominant canopy tree seedlings belongs to four genera (Dipterocarpus, Shorea, Mesua and Syzygium) in families of Dipterocarpace, Clusiaceae and Myrtaceae. We investigated how the foliar traits would differ among species due to canopy openings and understory light environments in Valley, Mid-slope and Ridge top topographic positions in Sinharaja forest. These results are important to understand niche differentiation of dominant canopy tree seedlings within the gap and the understory environments across the forest topography of the rain forest.

\section{MATERIALS AND METHODS}

\subsection{STUDY SITE AND SPECIES}

This study was conducted at Sinharaja rain forest. The topography in this forest is undulating and approximately $600 \mathrm{~m}$ a.m.s.l with different elevation between valleys to ridge top generally less than $100 \mathrm{~m}$. Samples were collected at three sites of each topographic position. Sites selected; valley position at Halmandiya Dola area, mid-slope position at, Westmane and 50 ac plot area. Mulawella and Wathurawa area were selected for ridge position. Total number of sites selected was nine. There were two plots in each topographic position; canopy opening and other was in understory. Experiment seedlings ware established by Ediriweera in 1999 as plot size was $2.4 \mathrm{~m} \times 2.4 \mathrm{~m}$ and seedling planting distance was $0.2 \mathrm{~m}$ from each other. There were sixteen seedlings per species per plot.

\subsection{STUDY SPECIES}

There were nine species in genera, Shorea (S. disticha (Thw.) Ashton, S. trapezifolia (Thw.) Ashton, S. megistophylla Ashton, S. worthingtonii Ashton), Dipterocarpus species ( D. zeylanicus Thw. ) Mesua species (M. nagassarium Kosterm and M. ferrea L.) and species of Syzygium ( S. makul Gaertn., S. rubicundum Wight and Arn.) used in this study. These species were selected since these are in the canopy/sub canopy strata. Leaf morphological and anatomical trails were measured in three seedlings from each tree species in one plot selected randomly and there were 27 leaves collected from one plot. The leaves that are fully expanded, undamaged were selected. Likewise one site has two plots; each topographic position has three sites.

\subsection{LEAF MORPHOLOGY}

Leaf morphological attributes of leaf area, length, leaf width, drip-tip length and petiole length were measured. The digital photo of each leaf was taken with a known scale (using a ruler) and was used to measure each of the above attributes using Image $\mathbf{J}$ software.

\subsection{LEAF ANATOMY}

Leaf anatomical, attributes of thickness leaf blade, upper and lower epidermal cell layer, palisade mesophyll cell layer $t$, cuticle layer and stomatal dencity (number of stomata per unit area) were measured. To measure differing attributes, leaf secions were taken and permanent slide were prepared. The photos of microscope view of the each anatomical structure were taken using Magnus live USB2.0 camera and each attribute were measured using Image J software. Number of stomata per unit area $\left(\mathrm{mm}^{-2}\right)$ was obtained from lower surface of the each leaf. Very thin layer of nail polish was placed in lower surface of the leaf. After few minutes that nail polish layer was peeled off and placed in to a glass slide and covered with cover slip. To count number of stomata per unit area, a photos of the micrographs taken from

Proceedings of the 15 $5^{\text {th }}$ International Forestry and Environment Symposium, 26-27 November 2010.

Published by Department of Forestry and Environmental Science, University of Sri Jayewardenepura, Sri Lanka. 
Magnus live USB2.0 camera. Number of stomata counted from three places in each leaf and was calculated per unit area $\left(\mathrm{mm}^{-2}\right)$.

\subsection{DATA ANALYSIS}

Both anatomical and morphological attributes were taken from leaves grown in (canopy gap and understory light environments) and in and three topographic positions (valley, mid-slope and gap) for each species. The response of each attribute to differing light and topographic position was tested using Analysis of Variance (ANOVA) using Minitab version 14.1. Each character was analyzed as species- light conditions and species- topographic positions.

\section{RESULTS}

\section{LEAF MORPHOLOGY}

The morphological traits of leaf area, length, petiole length had significant differences $(\mathrm{P}<$ 0.05) due to differing topographic positions, light and species (Table 1). In general morphological attributes were greater canopy gaps than in the understory. S. makul and $S$. rubicundum had the highest stomatal frequency in both light conditions across all topographic positions. Leaf area and length were higher for S. megistophylla than other species in both light and topographic positions. D. zeylanicus was greater in petiole length both light environments.

According to traits of leaf blade, upper epidermal and palisade layer thickness had significant differences $(\mathrm{P}<0.05)$ to changes in light environments across of topographies. The measured traits were also significantly different among the nine species (Table 1). Similer to morphological traits, anatomical attributes were also greater in canopy gaps than understory. S. makul had the higher leaf blade thickness while S. megistophylla was the higher in palisade layer and upper epidermal thickness in both light and topographies.

Table 1: Analysis of variance (ANOVA) on stomatal frequency $\left(\mathrm{cm}^{-2}\right)$, leaf area $\left(\mathrm{cm}^{2}\right)$, leaf length $(\mathrm{cm})$, leaf width $(\mathrm{cm})$, leaf petiole length $(\mathrm{cm})$, leaf drip-tip length $(\mathrm{cm})$, thickness of leaf blade $(\mu \mathrm{m})$, upper epidermis $(\mu \mathrm{m})$, palisade mesophyll $(\mu \mathrm{m})$, lower epidermisl $(\mu \mathrm{m})$ and cuticle $(\mu \mathrm{m})$ of seedlings of nine tree species in two light conditions (canopy gap and understory) across three topographic positions (valley, mid-slope, ridge). Degree of significance: $* \mathrm{P}<0.05$. ns denote not significance

SD-Stomatal density, LA- Leaf Area, LL- Leaf Length, LW-Leaf Width, LD- Leaf Drip-tip length, LP- Leaf Petiole, BT- thickness of Leaf Blade, UE- Upper Epidermis, PM- palisade Mesophyll, LE- Lower Epidermis, CT- Cuticle.

\begin{tabular}{lllllllllllll}
\hline & df & SD & LA & LL & LW & LD & LP & BT & UE & PM & LE & CT \\
\hline Topography & 2 & $*$ & $*$ & $*$ & $*$ & $*$ & $*$ & $*$ & $*$ & $*$ & $*$ & $\mathrm{~ns}$ \\
Light & 1 & $*$ & $*$ & $*$ & $*$ & $*$ & $*$ & $*$ & $*$ & $*$ & $*$ & $*$ \\
Species & 8 & $*$ & $*$ & $*$ & $*$ & $*$ & $*$ & $*$ & $*$ & $*$ & $*$ & $*$ \\
Topography $\times$ Light & 2 & $*$ & $\mathrm{~ns}$ & $\mathrm{~ns}$ & $*$ & $\mathrm{~ns}$ & $*$ & $*$ & $*$ & $*$ & $\mathrm{~ns}$ & $\mathrm{~ns}$ \\
Topography $\times$ species & 16 & $*$ & $*$ & $*$ & $\mathrm{~ns}$ & $*$ & $\mathrm{~ns}$ & $*$ & $*$ & $*$ & $*$ & $*$ \\
Species $\times$ Light & 8 & $*$ & $*$ & $*$ & $*$ & $*$ & $*$ & $*$ & $*$ & $\mathrm{~ns}$ & $*$ & $*$ \\
$\begin{array}{l}\text { Topography } \times \text { Light } \times \\
\text { species }\end{array}$ & 16 & $*$ & $*$ & $*$ & $\mathrm{~ns}$ & $*$ & $\mathrm{~ns}$ & $*$ & $*$ & $*$ & $\mathrm{~ns}$ & $\mathrm{~ns}$
\end{tabular}

Proceedings of the $15^{\text {th }}$ International Forestry and Environment Symposium, 26-27 November 2010. 


\section{DISCUSSION}

The combination of leaf anatomical and morphological attributes can constitute part of physiological tolerance of a species (Ashton, 1990). Anatomical and morphological characters can be use to identify the niche differentiation of a species to a particular environment. Considering Dipterocarpus zeylanicus each anatomical attributes were higher in canopy gaps than in the understory. In gap condition most of the anatomical attributes are susceptible for mid-slope. According to Ediriweera (2008), D. zeylanicus has shown best growth performance in low elevations. It is the canopy dominated and adapted in low elevations and near water ways (Ashton, 2001). But according to this study anatomical and morphological characters are not suitable for that topography. This is more likely to be due to other environmental factors that affected growth of D. zeylanicus.

Considering the selected anatomical characters of the Mesua ferrea it is adapted to the valley in the gap condition. It is proved by $M$. ferrea is a slow-growing, shade tolerance species restricted to valleys(Ashton et al., 1997). But morphologically it was adapted to the midslope. Our results showed that in understory, M. ferrea is restricted to the mid-slope. Due to thick lower epidermal layer of $M$. ferrea there stomata can not be taken. Stomatal frequency for M. ferrea is not analyzed in this study. Mesua nagassarium is the relatively shade-tolerant species. But considering the anatomy, all leaf attributes were higher in canopy gaps than in the understory. Anatomically it is more adapted to ridge sites. Leaf morphological characters also show that $M$. nagassarium is suitable for ridge than the other topographic positions. It can alos be identified from both anatomical and morphological traits in the understory that $M$. nagassarium is more adapted to the ridge. Shorea disticha showed relatively less shade tolerant foliar traits s than Shorea worthingtonii but the tolerant is more than the other two Shorea species (Ediriweera, 2008). Leaf blade thickness and the palisade mesophyll thickness of Shorea disticha were higher in ridge sites. Most of the morphological characters such as leaf area, leaf petiole length were also higher in ridge sites. However, distribution of S. disticha is in the mid-slope (Ashton et al., 2001). Plant distribution affected to the different factors, such as soil nutrition, niche compitiion, and water availability. Due to that reasons $S$. disticha can not be recommended to that habitat.

Shorea megistophylla is relatively shade intolerant species (Ashton, 1990; 1995).to and is a canopy dominant tree restricted to bottom slope and seepage ways (Ashton et.al. 2001). According to these results both anatomical and morphological characters were greater with increased light. The selected anatomical and morphological attributes of S.megistophylla suggest that it is more adapted to valley sites. It has also shown that S.megistophylla produce large leaves to capture more light because this species restricted to light limiting low and valet bottom area (Ediriweera, 2008) . Foliar traits in the understory condition (Fig. 1, 2) also suggest that S.megistophylla is adapted to valley sites.

Shorea trapezifolia is relatively shade intolerant canopy dominant tree restricted to exposed to mid to lower slopes (Ashton et.al. 2001). But considering both anatomical and morphological attributes of this study $S$. trapezifolia is more adapted to mid-slope and ridge top sites. Previous studies have shown that $S$. trapezifolia is adapted to lower slopes of valleys within forest topography (Ashton, 1990). The measured anatomical characters increased with light. Therefore, our results suggest that $S$. trapezifolia is adapted to valley sites. Shorea worthingtonii is more shade tolerant than other studied Shorea species (Ashton, 1990). Considering all attributes of anatomy and morphology for $S$. worthingtonii is more adapted to canopy gaps. Because anatomical and morphological characters were different across topographies and higher in mid-slopes (Figs. 1, 2).

Proceedings of the 15 $5^{\text {th }}$ International Forestry and Environment Symposium, 26-27 November 2010.

Published by Department of Forestry and Environmental Science, University of Sri Jayewardenepura, Sri Lanka. 
Syzygium makul, is mostly restricted to mid-slopes. Syzygium makul in lowland rain forest shows that this species grows well in lower mid-slopes (Ediriweera, 2008). Gamage (2000) also provided evidence that Syzygium makul is adapted to the lower mid-slope sites. This is true for the canopy gap sites as well as understories. Syzygium makul was the least shade tolerant species. Both anatomical and morphological attributes show higher values in canopy gaps than the understory.

Syzygium rubicundum is a shade intolerant species (Gamge 2000). We found that $S$. rubicundum having greaterh anatomical and morphological attributes in the understory than in canopy gaps. Generally considering the anatomical and morphological characters, it can be expressed $S$. rubicundum is more adapted to mid-slope than other topographies. It is proved by growth performance of S. rubicundum (Ediriweera 2008).

\section{CONCLUSION}

Leaf anatomical and morphological characters are varying with the light condition (gap and understory) within topography. Out of the anatomical and morphological characters, highest values of the each attribute were obtained in gaps for all species compared. Foliar traits also varied across three topographic positions. Thus, it can be identified that each species is anatomically and morphologically more adapted to a particular environment within the forest. These adaptations can vary with other environmental factors in the forest.

Table 2: Mean values of the morphological attributes of canopy tree species between gaps and understory and across topographies (Valley, Mid-slope, and Ridge). Standard errors of means in brackets and simple letters along the rows denote differences of the each attribute between light conditions and capital letters along the columns denote differences of each attribute across the topographies of the same species at 5\% level of significance. Species followed by same latter are not significantly different.

Table 3: Mean values of the anatomical attributes of canopy tree species between gaps and understory and across topographies (Valley, Mid-slope, and Ridge). Standard errors of means in brackets and simple letters along the rows denote differences of the each attribute between light conditions and capital letters along the columns denote differences of each attribute across the topographies of the same species at 5\% level of significance. Species followed by same latter are not significantly different. 


\begin{tabular}{|c|c|c|c|c|c|c|c|c|c|}
\hline \multirow[b]{2}{*}{ (a) Valley } & \multirow[t]{2}{*}{ SD Gap } & \multirow[t]{2}{*}{ SD Understory } & \multirow[t]{2}{*}{ LA Gap } & LA Understory & LL Gap & \multicolumn{2}{|c|}{ LL Understory } & LP Gap & LP Understory \\
\hline & & & & & & & & & \\
\hline D.zeylanicus & $280.60(10.80) \mathrm{A} \mathrm{a}$ & $218.80(12.00) \mathrm{A} \mathrm{b}$ & $123.90(24.90) \mathrm{A} \mathrm{a}$ & $53.67(*)$ & $22.64(2.10) \mathrm{A} \mathrm{a}$ & $13.73(*)$ & A a & $2.67(0.37)$ & $1.03(*)$ \\
\hline M.ferrea & & & $107.10(10.60) \mathrm{A} \mathrm{a}$ & $63.50(11.20) \mathrm{A} \mathrm{b}$ & $21.45(1.64) \mathrm{A} \mathrm{a}$ & $15.74(135)$ & $\mathrm{Ab}$ & $0.93(0.08)$ & $0.93(0.10) \mathrm{A} \mathrm{a}$ \\
\hline M.nagassarium & $169.67(8.57) \quad \mathrm{A} \mathrm{a}$ & $144.00(7.61) \mathrm{A} \mathrm{b}$ & $33.88(5.57) \quad \mathrm{A} \mathrm{a}$ & $23.19(3.84) \mathrm{A} \mathrm{a}$ & $11.48(0.61) \mathrm{A} \mathrm{a}$ & $10.13(0.89)$ & $\mathrm{Ab}$ & $0.66(0.02)$ & $0.603(0.06) \mathrm{A} \mathrm{a}$ \\
\hline S.disticha & 161.67(6.15) A a & $130.38(8.64) \mathrm{A} \mathrm{b}$ & $46.89(3.38) \quad \mathrm{A} \mathrm{a}$ & $33.00(4.54) \mathrm{A} \mathrm{b}$ & $13.53(0.65) \mathrm{A} \mathrm{a}$ & $11.11(1.38)$ & $\mathrm{Ab}$ & $0.71(0.07)$ & $0.65(0.03) \mathrm{Ab}$ \\
\hline S.megistophylla & $204.31(0.70) \mathrm{AB}$ a & $162.75(7.25) \quad \mathrm{A} \mathrm{b}$ & $159.80(33.80) \mathrm{A} \mathrm{a}$ & $89.10(15.00) \mathrm{A} \mathrm{b}$ & $25.32(2.29) \mathrm{A} \mathrm{a}$ & $18.86(0.70)$ & $\mathrm{Ab}$ & $1.28(0.20)$ & $0.87(0.08) \mathrm{A} \mathrm{b}$ \\
\hline S.trapezifolia & $266.90(20.10) \mathrm{A} \mathrm{a}$ & $147.00(8.13) \mathrm{A} \mathrm{b}$ & $12.90(1.06) \quad \mathrm{A} \mathrm{a}$ & $14.70(2.37) \quad \mathrm{A} \mathrm{a}$ & $8.48(0.38) \mathrm{A} \mathrm{a}$ & $9.21(0.70)$ & A a & $0.37(0.04) \quad \mathrm{A} \mathrm{a}$ & $0.37(0.03) \mathrm{A} \mathrm{b}$ \\
\hline S.worthingtonii & $169.20(11.80) \mathrm{A} \mathrm{a}$ & $115.10(10.10) \mathrm{A} \mathrm{b}$ & $20.30(2.97) \quad \mathrm{A} \mathrm{a}$ & $12.65(3.08) \mathrm{A} \mathrm{a}$ & $11.27(0.81) \mathrm{A} \mathrm{a}$ & $9.76(0.96)$ & $\mathrm{A}$ a & $0.749(0.11) \mathrm{A} \mathrm{a}$ & $0.53(0.10) \mathrm{Ab}$ \\
\hline S.makul & $509.30(64.80) \mathrm{A} \mathrm{a}$ & $280.50(14.00) \mathrm{A} \mathrm{b}$ & $64.30(10.30) \mathrm{A} \mathrm{a}$ & $43.13(5.99) \quad \mathrm{Ab}$ & $14.86(1.08) \mathrm{A} \mathrm{a}$ & $14.28(1.17)$ & $\mathrm{A}$ a & $1.21(0.12) \quad \mathrm{A} \mathrm{a}$ & $0.78(0.12) \mathrm{A} \mathrm{a}$ \\
\hline $\begin{array}{l}\text { S.rubicundum } \\
\text { (b)Mid-slope }\end{array}$ & $449.10(25.90) \mathrm{A} \mathrm{a}$ & $344.40(38.50) \mathrm{A} \mathrm{b}$ & $6.09(0.40) \quad \mathrm{A} \mathrm{a}$ & $5.25(0.25) \quad \mathrm{A} \mathrm{a}$ & $5.55(5.31) \mathrm{A} \mathrm{a}$ & $5.31(0.11)$ & A a & $0.43(0.03)$ & $0.35(0.02) \mathrm{A} \mathrm{a}$ \\
\hline D.zeylanicus & $258.30(13.20) \mathrm{B}$ a & $186.67(8.04) \mathrm{A} \mathrm{b}$ & $215.50(44.30)$ & $86.30(16.60) \mathrm{A} \mathrm{b}$ & $26.37(2.99) \mathrm{A} \mathrm{a}$ & $18.47(1.74)$ & $\mathrm{A}$ a & $3.36(0.65)$ & $2.03(0.30) \mathrm{Ab}$ \\
\hline M.ferrea & & & $115.50(14.50) \mathrm{A} \mathrm{a}$ & $35.58(2.11) \mathrm{Ab}$ & $22.35(1.36) \mathrm{A} \mathrm{a}$ & $14.49(1.17)$ & $\mathrm{Ab}$ & $0.90(0.13)$ & $0.62(0.06) \mathrm{B} \mathrm{a}$ \\
\hline M.nagassarium & $222.00(12.20) \mathrm{A} \mathrm{a}$ & $181.40(15.00) \mathrm{A} \mathrm{b}$ & $44.32(4.5)$ & $38.60(10.70) \mathrm{A} \mathrm{a}$ & $13.5790 .61) \mathrm{B} \mathrm{a}$ & $10.34(0.54)$ & $\mathrm{Ab}$ & $0.79(0.06)$ & $0.51(0.08) \mathrm{A} \mathrm{a}$ \\
\hline S.disticha & $192.86(7.74) \mathrm{B} \mathrm{a}$ & $130.00(17.70) \mathrm{A} \mathrm{b}$ & $69.66(8.06)$ & $42.33(3.97) \quad \mathrm{A} \mathrm{b}$ & $16.14(0.99) \mathrm{B} \mathrm{a}$ & $13.00(0.51)$ & $\mathrm{Ab}$ & $0.98(0.09)$ & $0.88(0.08) \mathrm{B} \mathrm{a}$ \\
\hline S.megistophylla & $189.29(7.02) \quad \mathrm{B} \mathrm{a}$ & $163.67(4.07) \mathrm{A} \mathrm{b}$ & $200.00(24.80)$ & $91.00(16.50) \mathrm{A} \mathrm{b}$ & $28.13(1.39) \mathrm{A} \mathrm{a}$ & $19.20(1.51)$ & $\mathrm{Ab}$ & $1.96(0.16) \quad \mathrm{B} \mathrm{a}$ & $1.17(0.13) \mathrm{A} \mathrm{a}$ \\
\hline S.trapezifolia & $248.80(11.00) \mathrm{A} \mathrm{a}$ & $204.20(14.40) \mathrm{B} \mathrm{b}$ & $20.17(1.41)$ & $13.20(1.04) \quad \mathrm{B} \mathrm{b}$ & $10.34(0.34) \mathrm{B} \mathrm{a}$ & $9.00(0.41)$ & $\mathrm{Ab}$ & $0.35(0.02) \quad \mathrm{A} \mathrm{a}$ & $0.31(0.04) \mathrm{A} \mathrm{a}$ \\
\hline S.worthingtonii & 197.627.70) $\mathrm{B} \mathrm{a}$ & $181.67(7.51) \quad \mathrm{B} \mathrm{a}$ & $27.54(2.62)$ & $24.86(3.86) \quad \mathrm{B} \mathrm{b}$ & $11.88(0.45) \mathrm{A} \mathrm{a}$ & $12.61(0.72)$ & $\mathrm{B}$ a & $0.97(0.09)$ & $0.59(0.09) \mathrm{Ab}$ \\
\hline S.makul & $454.70(20.00) \mathrm{B} \mathrm{a}$ & $377.20(2670) \mathrm{A} \mathrm{b}$ & $88.90(11.70) \quad \mathrm{A} \mathrm{a}$ & $50.57(6.05) \quad \mathrm{A} \mathrm{b}$ & $17.63(1.07) \mathrm{A} \mathrm{a}$ & $15.60(0.99)$ & $\mathrm{A}$ a & $1.35(0.08)$ & $1.10(0.11) \mathrm{A} \mathrm{a}$ \\
\hline $\begin{array}{l}\text { S.rubicundum } \\
\text { (c) Ridge }\end{array}$ & $407.40(18.60) \mathrm{A} \mathrm{a}$ & $337.40(21.50) \mathrm{A} \mathrm{b}$ & $7.17(0.44) \quad \mathrm{A} \mathrm{a}$ & 5.64(0.70) $\mathrm{ABa}$ & $5.81(0.24) \mathrm{A} \mathrm{a}$ & $5.32(0.27)$ & $\mathrm{A} \mathrm{a}$ & $0.47(0.05) \quad \mathrm{A} \mathrm{a}$ & $0.42(0.04) \mathrm{ABa}$ \\
\hline D.zeylanicus & $216.70(12.40) \mathrm{B} \mathrm{a}$ & $180.00(11.00) \mathrm{A} \mathrm{b}$ & $278.00(45.50)$ & $49.30(*)$ & $30.60(3.77) \mathrm{A} \mathrm{a}$ & $14.74(*)$ & $\mathrm{Ab}$ & $4.23(0.63)$ & $1.33(*) \quad \mathrm{A} \mathrm{b}$ \\
\hline M.ferrea & & & $106.50(15.80)$ & $50.55(9.09) \mathrm{ABb}$ & $20.67(1.52) \quad \mathrm{A} \mathrm{a}$ & $14.30(1.03)$ & $\mathrm{Ab}$ & $0.97(0.06)$ & $0.79(0.05 \mathrm{AB} b$ \\
\hline M.nagassarium & $250.60(13.50) \mathrm{B} \mathrm{a}$ & $202.80(12.10) \mathrm{A} \mathrm{b}$ & $45.46(3.35) \quad \mathrm{A} \mathrm{a}$ & $23.47(2.32) \mathrm{A} \mathrm{b}$ & $13.11(0.56) \mathrm{A} \mathrm{a}$ & $9.64(0.31)$ & $\mathrm{Ab}$ & $0.79(0.06)$ & $0.66(0.03) \mathrm{A} \mathrm{a}$ \\
\hline S.disticha & $211.11(9.42) \quad \mathrm{B} \mathrm{a}$ & $172.20(14.10) \mathrm{A} \mathrm{b}$ & $54.00(5.11) \mathrm{AB} a$ & $36.20(1.78) \mathrm{A} \mathrm{b}$ & $13.55(0.65) \mathrm{AB}$ a & $12.08(0.33)$ & A a & $1.11(0.10) \quad \mathrm{B} \mathrm{a}$ & $0.85(0.06) \mathrm{B} \mathrm{b}$ \\
\hline S.megistophylla & $222.20(15.80) \mathrm{A} \mathrm{a}$ & $172.22(8.78) \mathrm{A} \mathrm{b}$ & $161.10(20.10) \quad \mathrm{A} \mathrm{a}$ & $68.83(7.35) \quad \mathrm{A} \mathrm{b}$ & $24.52(1.26) \mathrm{A} \mathrm{a}$ & $18.36(0.91)$ & $\mathrm{Ab}$ & $1.63(0.15) \mathrm{AB} a$ & $0.98(0.14) \mathrm{Ab}$ \\
\hline S.trapezifolia & $288.90(21.30) \mathrm{A} \mathrm{a}$ & $208.30(15.40) \mathrm{B} \mathrm{b}$ & $15.95(1.17)$ & $10.48(1.37) \mathrm{A} \mathrm{b}$ & $9.52(0.38) \quad \mathrm{A} \mathrm{a}$ & $7.77(0.45)$ & $\mathrm{Ab}$ & $0.39(0.03) \quad \mathrm{A} \mathrm{a}$ & $0.23(0.04) \mathrm{Ab}$ \\
\hline S.worthingtonii & $170.00(11.50) \mathrm{A} \mathrm{a}$ & $153.80(17.90) \mathrm{B} \mathrm{a}$ & $30.55(2.57)$ & $13.46(1.66) \quad \mathrm{B} \mathrm{b}$ & $12.99(0.41) \quad \mathrm{A} \mathrm{a}$ & $9.54(0.52)$ & $\mathrm{Ab}$ & $1.00(0.12)$ & $0.62(0.06) \mathrm{Ab}$ \\
\hline S.makul & $480.60(14.90) \mathrm{A} \mathrm{a}$ & $325.00(25.00) \mathrm{A} \mathrm{b}$ & $64.72(6.24)$ & $13.90(7.10) \quad \mathrm{B} \mathrm{b}$ & $15.14(0.83) \quad \mathrm{A} \mathrm{a}$ & $7.46(2.44)$ & $\mathrm{B} \mathrm{b}$ & $1.08(0.08)$ & $0.66(0.17) \mathrm{Ab}$ \\
\hline S.rubicundum & $438.30(22.90) \mathrm{B} \mathrm{a}$ & $306.30(51.00) \mathrm{A} \mathrm{b}$ & $5.67(384)$ & $3.84(0.31) \quad \mathrm{B} \mathrm{b}$ & $5.25(0.16) \mathrm{A} \mathrm{a}$ & $4.97(0.20)$ & $\mathrm{B}$ a & $0.45(0.05)$ & $0.50(0.03) \mathrm{B} \mathrm{b}$ \\
\hline
\end{tabular}

Proceedings of the 15 $5^{\text {th }}$ International Forestry and Environment Symposium, 26-27 November 2010.

Published by Department of Forestry and Environmental Science, University of Sri Jayewardenepura, Sri Lanka. 


\begin{tabular}{|c|c|c|c|c|c|c|}
\hline \multirow[b]{2}{*}{ (a) Valley } & BT Gap & BT Understory & UE Gap & UE Understory & PM Gap & PMUnderstory \\
\hline & & & & & & \\
\hline D.zeylanicus & $135.48(6.66) \mathrm{AB}$ a & $115.52(3.83) \mathrm{Ab}$ & $23.69(0.77) \quad \mathrm{A} \mathrm{a}$ & $17.32(1.51) \mathrm{AB} b$ & $26.32(0.56) \quad \mathrm{A} \mathrm{a}$ & $21.97(0.89) \mathrm{A} \mathrm{b}$ \\
\hline M.ferrea & $173.3(11.00) \quad \mathrm{A} \mathrm{a}$ & $130.22(5.66) \mathrm{A} \mathrm{b}$ & $14.16(0.84) \quad \mathrm{A} \mathrm{a}$ & $10.81(0.66) \quad \mathrm{Ab}$ & $27.93(2.29) \quad \mathrm{A} \mathrm{a}$ & $19.64(1.06) \mathrm{A} \mathrm{b}$ \\
\hline M.nagassarium & $160.41(8.00) \quad \mathrm{A} \mathrm{a}$ & $126.56(4.73) \quad \mathrm{Ab}$ & $16.18(0.68) \quad \mathrm{A} \mathrm{a}$ & $12.61(1.02) \mathrm{A} \mathrm{b}$ & $28.86(2.56) \quad \mathrm{A} \mathrm{a}$ & $20.27(0.79) \mathrm{A} \mathrm{b}$ \\
\hline S.disticha & $205.61(6.07) \quad \mathrm{A} \mathrm{a}$ & $182.59(5.07) \mathrm{AB} \mathrm{b}$ & $25.35(0.73)$ & $22.30(0.67) \quad \mathrm{A} \mathrm{b}$ & $52.79(1.34) \quad \mathrm{A} \mathrm{a}$ & 48.13(0.99)AB b \\
\hline S.megistophylla & $211.08(9.55) \quad \mathrm{A} \mathrm{a}$ & $172.46(6.17) \quad \mathrm{Ab}$ & $26.76(1.09) \quad \mathrm{A} \mathrm{a}$ & $21.45(0.64) \mathrm{AB} b$ & $59.82(2.46) \quad \mathrm{A} \mathrm{a}$ & $52.46(2.03) \mathrm{A} \mathrm{b}$ \\
\hline S.trapezifolia & $121.19(3.75) \mathrm{AB} a$ & $116.51(5.02) \quad \mathrm{Ab}$ & $21.03(0.56) \quad \mathrm{A} \mathrm{a}$ & $19.95(0.78) \quad \mathrm{Ab}$ & $40.49(1.16) \quad \mathrm{A} \mathrm{a}$ & $32.96(2.13) \mathrm{A} \mathrm{b}$ \\
\hline S.worthingtonii & $127.21(4.07) \quad \mathrm{A} \mathrm{a}$ & $114.88(2.06) \quad \mathrm{A} \mathrm{a}$ & $22.76(0.94) \quad \mathrm{A} \mathrm{a}$ & $19.23(0.67) \quad \mathrm{A} \mathrm{b}$ & $41.29(1.53) \mathrm{AB} a$ & $35.01(0.95) \mathrm{A} \mathrm{b}$ \\
\hline S.makul & $250.49(8.84) \quad \mathrm{A} \mathrm{a}$ & $220.7(10.70) \mathrm{AB} b$ & $11.22(0.51) \quad \mathrm{A} \mathrm{a}$ & $9.18(0.44) \quad \mathrm{A} \mathrm{b}$ & $49.26(1.47) \mathrm{AB} a$ & $44.47(1.70) \mathrm{A} \mathrm{b}$ \\
\hline $\begin{array}{l}\text { S.rubicundum } \\
\text { (b)Mid-slope }\end{array}$ & $146.30(5.65) \mathrm{A} \mathrm{a}$ & $107.69(3.81) \mathrm{A} \mathrm{b}$ & 15.82(099) & $12.48(0.75) \quad \mathrm{A} \mathrm{b}$ & $33.11(1.29) \mathrm{A} \mathrm{a}$ & $30.18(0.87) \mathrm{Ab}$ \\
\hline D.zeylanicus & $141.37(4.39) \quad \mathrm{A} \mathrm{a}$ & $127.55(4.01) \quad \mathrm{B} \mathrm{b}$ & $22.94(0.59) \quad \mathrm{A} \mathrm{a}$ & $20.42(0.39) \quad \mathrm{A} \mathrm{b}$ & $27.31(0.43) \quad \mathrm{A} \mathrm{a}$ & $24.70(0.49) \mathrm{A} \mathrm{b}$ \\
\hline M.ferrea & $171.12(7.11) \quad \mathrm{A} \mathrm{a}$ & $130.60(5.25)$ & $14.67(1.30) \quad \mathrm{A} \mathrm{a}$ & $10.29(0.59) \quad \mathrm{A} \mathrm{b}$ & $35.58(1.40) \quad \mathrm{A} \mathrm{a}$ & $23.17(1.02) \mathrm{A} \mathrm{b}$ \\
\hline M.nagassarium & $178.69(9.32) \mathrm{A} \mathrm{a}$ & $147.11(7.40) \quad \mathrm{A} \mathrm{b}$ & $16.30(1.35) \quad \mathrm{A} \mathrm{a}$ & $13.46(0.58) \quad \mathrm{A} \mathrm{b}$ & $32.29(0.96) \quad$ B & $28.57(1.20) \mathrm{A} \mathrm{b}$ \\
\hline S.disticha & $204.85(4.93) \quad \mathrm{A} \mathrm{a}$ & $173.18(3.86) \mathrm{Ab}$ & $23.25(0.56) \quad \mathrm{B} \mathrm{a}$ & $21.68(0.53) \quad \mathrm{A} \mathrm{b}$ & $54.75(1.06) \quad \mathrm{A} \mathrm{a}$ & $47.60(1.10) \mathrm{A} \mathrm{b}$ \\
\hline S.megistophylla & $200.44(4.75) \quad \mathrm{A} \mathrm{a}$ & $179.37(4.73)$ & $25.68(0.49)$ & $22.74(0.49) \quad \mathrm{A} \mathrm{b}$ & $53.09(1.41) \quad \mathrm{A} \mathrm{a}$ & 44. 36(1.41) B b \\
\hline S.trapezifolia & $119.68(3.41) \quad \mathrm{A} \mathrm{a}$ & $108.67(2.31) \quad \mathrm{Ab}$ & $19.00(0.55) \quad \mathrm{B} \mathrm{a}$ & $17.26(0.39) \quad \mathrm{A} \mathrm{b}$ & $39.41(1.05) \quad \mathrm{B} \mathrm{a}$ & $35.83(1.05) \mathrm{B} \mathrm{b}$ \\
\hline S.worthingtonii & $134.57(3.96) \quad \mathrm{B} \mathrm{a}$ & $113.22(3.97) \quad \mathrm{B} \mathrm{b}$ & $23.03(0.53) \quad \mathrm{A} \mathrm{a}$ & $21.72(0.52) \quad \mathrm{A} \mathrm{b}$ & $38.50(0.67) \quad \mathrm{A} \mathrm{a}$ & $35.28(0.67) \mathrm{B} \mathrm{b}$ \\
\hline S.makul & $259.33(7.03) \quad \mathrm{A} \mathrm{a}$ & $242.19(4.49) \quad$ B b & $12.59(0.25) \mathrm{AB} a$ & $10.71(0.21) \quad \mathrm{Ab}$ & $45.33(0.81) \quad \mathrm{A} \mathrm{a}$ & $42.79(0.81) \mathrm{A} \mathrm{b}$ \\
\hline $\begin{array}{l}\text { S.rubicundum } \\
\text { (C) Ridge }\end{array}$ & $129.61(2.81) \quad \mathrm{B} \mathrm{a}$ & $113.92(2.65)$ & $15.95(0.47) \quad \mathrm{A} \mathrm{a}$ & $12.65(0.35) \quad \mathrm{Ab}$ & $34.23(0.50) \quad \mathrm{A} \mathrm{a}$ & $31.00(0.50) \mathrm{A} \mathrm{b}$ \\
\hline D.zeylanicus & $131.16(5.87) \quad \mathrm{B} \mathrm{a}$ & $103.44(3.24) \quad \mathrm{B} \mathrm{b}$ & $21.15(0.58)$ & $17.90(1.17) \quad \mathrm{B} \mathrm{b}$ & $27.11(0.78) \quad \mathrm{A} \mathrm{a}$ & $22.30(0.92) \mathrm{A} \mathrm{b}$ \\
\hline M.ferrea & $162.2(6.25)$ & $144.95(5.08) \quad \mathrm{B} \mathrm{b}$ & $12.37(0.73) \quad \mathrm{A} \mathrm{a}$ & $9.62(0.65) \quad \mathrm{Ab}$ & $26.38(1.70) \quad \mathrm{A} \mathrm{a}$ & $21.44(1.44) \mathrm{A} \mathrm{b}$ \\
\hline M.nagassarium & $181.64(8.17) \quad \mathrm{A} \mathrm{a}$ & $158.57(3.71) \mathrm{A} \mathrm{b}$ & $17.36(1.36) \quad \mathrm{A} \mathrm{a}$ & $13.94(0.54) \mathrm{A} \mathrm{b}$ & $28.01(1.22) \quad \mathrm{A} \mathrm{a}$ & $24.02(0.62) \mathrm{A} \mathrm{b}$ \\
\hline S.disticha & $235.11(4.56) \quad \mathrm{B} \mathrm{a}$ & $190.84(5.19) \quad \mathrm{B} \mathrm{b}$ & $24.42(0.54) \mathrm{AB}$ a & $21.61(0.58) \quad \mathrm{Ab}$ & $55.51(1.15) \quad \mathrm{A} \mathrm{a}$ & $51.07(1.23) \mathrm{B} \mathrm{b}$ \\
\hline S.megistophylla & $191.20(4.62) \quad \mathrm{A} \mathrm{a}$ & $161.20(11.70) \mathrm{B} \mathrm{b}$ & $25.28(0.53) \quad \mathrm{A} \mathrm{a}$ & $22.91(0.69) \quad$ B b & $48.97(1.80) \quad \mathrm{A} \mathrm{a}$ & $41.52(0.77) \mathrm{B} \mathrm{b}$ \\
\hline S.trapezifolia & $133.72(4.22) \quad \mathrm{B} \mathrm{a}$ & $111.32(7.70) \mathrm{Ab}$ & $21.18(0.56)$ & $15.41(0.83) \quad \mathrm{Ab}$ & $40.87(1.10) \quad \mathrm{B} \mathrm{a}$ & $33.40(1.75) \mathrm{B} \mathrm{b}$ \\
\hline S.worthingtonii & $146.14(4.45) \quad \mathrm{B} \mathrm{a}$ & $132.40(3.93) \mathrm{A} \mathrm{b}$ & $23.66(0.63)$ & $20.31(0.71) \quad \mathrm{Ab}$ & 42.44(1.17) $\mathrm{B} \mathrm{a}$ & $36.73(1.20) \mathrm{B} \mathrm{b}$ \\
\hline S.makul & $259.91(10.00) \mathrm{A} \mathrm{a}$ & $188.30(21.80) \mathrm{A} \mathrm{b}$ & $13.21(0.60)$ & $9.90(0.41) \quad \mathrm{A} \mathrm{b}$ & $52.34(1.79) \quad \mathrm{B} \mathrm{a}$ & $38.58(2.56) \mathrm{A} \mathrm{b}$ \\
\hline S.rubicundum & $140.48(3.34) \quad \mathrm{A} \mathrm{a}$ & $127.01(3.75) \mathrm{B} \mathrm{b}$ & $14.90(0.49)$ & $12.21(0.37) \quad \mathrm{Ab}$ & $32.33(0.60) \quad \mathrm{A} \mathrm{a}$ & $29.40(1.35) \mathrm{A}$ \\
\hline
\end{tabular}

Proceedings of the 15 ${ }^{\text {th }}$ International Forestry and Environment Symposium, 26-27 November 2010.

Published by Department of Forestry and Environmental Science, University of Sri Jayewardenepura, Sri Lanka. 


\section{REFERENCES}

Ashton, P.M.S (1990). Method of the evaluation of advanced regeneration in forest types of souh and southeast Asia. Forest Ecology and management 36:163-175

Ashton, P.M.S (1995). Seedling growth of co-occurring Shorea species in the simulated light environment of rainforest. Forest ecology and management 72:1-12

Ashton, P.M.S and Berlyn, G.P. (1994) A comparison of leaf physiology and anatomy of Quercus(section Erytrhobalanus- Fagaceae) species in different light environments. Americal Journal of Botany, 81(5), 589-597.

Ashton, P.M.S., Gunatilleke, C.V.S \& Gunatilleke, IA U.N.(1997) Seedling survival and growth of four Shorea species in Sri lankan rain forest. Journal of Tropical Ecology, II, 263-279).

Ashton, P.M.S., Gunatilleke, C.V.S., Singhakumara, BM.P., Gunatilleke, I.A.U.N. (2001) Restoration pathways for rain forest in southwest Sri lanka: A review of concepts and models. Forest Ecology and Management. 154, 409-430.

Brokaw, N.V.L (1985) Gap-phase regeneration in a tropical forest. Ecology 66(3) 882-887.

Brown, N.D. (1995). The implication of climate and gap micro climate for seedling growth conditions in a Bornean lowland rain forest. Journal of Tropical Ecology 9:153-168.

Canham, C.D. (1989). Growth and canopy architecture of shade tolerant trees: Response to canopy gaps.Ecology 69 3: 786-795)

Canham, C.D., Denslow, J.S., Platt, W.J., Runkle, T., Spies, A. \& White, P.S. (1990). Light regimes beneath closed canopies and tree fall gaps in temperate and tropical forests. Canadian Journal of Forest Research 20: 620-631.

Ediriweera, E.P.S.K. (2008). Study on competition among late-successional tree seedlings across a topographic cantena of a Sri Lankan rain forest.

Feeley, J.K, Davies, S.J, Ashton, P.S, Bunyavejchewin,S, (2007). The role of gap phase processes in the biomass dynamics of tropical forests . The royal society. 274, 2857-2864

Gamage, H.K.,Ashton, P.M.S. \&Singhakumara, B.M.P. (2003). Leaf structure of Syzygium Spp (Myrtaceac) in relation to site affinity within a tropical rain forest. Botanical Journal of the Linnean Society 141:365-377.

Gunatilleke, C.V.S \& Gunatilleke, I.A.U.N. (1985). Phytosociology of Sinharaja- a contribution to rain forest conservation.

Raich, J.W. \& Khoon, G.W. (1990). Effect of canopy openings on tree seed germination in a Malayasian dipterocarp forest. Journal of Tropical Ecology 6: 203-217.

Reich, P.B. (1995) Phenology of tropical forests: patterns, causes, and consequence. Canadian journal of botany 73: 164-174.

Singhakumara, B.M.P, Gamage, H., and Ashton, M.S. (2003) Comparative growth of four Sysygium species within simulated shade environments of Sri lankan rain forest. Forest Ecology and management, 174, 511-520.

Whitmore, T.C. (1978). Gaps in the forest canopy. Tomlinson, P.B. \& Zimmerman, M.H. eds( Tropical trees as living systems. Cambridge University press, Cambridge UK. 639-655pp. 